\title{
Comparison between the Rapid ID 32 Strep test system and 16S rRNA gene sequencing for the identification of $\alpha$-hemolytic streptococci
}

\author{
Si Young Lee*
}

Professor, Department of Microbiology and Immunology, College of Dentistry, Research Institute of Oral Science, Gangneung-Wonju National University, Gangneung, Republic of Korea

Oral viridans streptococcus is the most common bacterial species present in human dental plaque. The Rapid ID 32 Strep (bioMerieux, Marcy-l'Etoile, France) test system allows for the identification of most streptococci within 4 hours. The aim of this study was to evaluate the reliability of this test in identifying isolates of $\alpha$-hemolytic oral streptococci in human dental plaque and compare it with that of the 16S rRNA sequencing method. A total of eighty-five $\alpha$-hemolytic streptococcal isolates were identified using $16 \mathrm{~S}$ rRNA gene sequencing and Rapid ID 32 Strep. The Rapid ID 32 Strep method correctly identified $80 \%$ of the species and $87 \%$ of the streptococcal groups but failed to accurately identify five isolates (three $S$. cristatus, one $S$. australis, and one $S$. tigurinus).

Key Words: Identification; Sequencing; Streptococci

(c) This is an open-access article distributed under the terms of the Creative Commons Attribution Non-Commercial License (http://creativecommons.org/licenses/by-nc/4.0) which permits unrestricted noncommercial use, distribution, and reproduction in any medium, provided the original work is properly cited.

\section{Introduction}

Oral viridans streptococci are the major bacterial species present in human dental plaque, and most oral streptococci are $\alpha$-hemolytic streptococci $[1,2]$. As the gold standard, 16S rRNA gene sequencing is used [3-6] for bacterial identification, with a sequence homology of $99 \%$ or greater with published species sequences considered to denote the same species, in accordance with Clinical \& Laboratory Standard Institute (CLSI) guidelines [7].

The API 20 Strep strip contains twenty microtubes with dehydrated substrates that are necessary to detect enzymatic activity and fermentation of sugars. The results are obtained within 24-48 hours, and the identification is based on numerical analysis after a visual interpretation of color changes (bioMérieux, Marcy-l'Etoile, France) [8]. Recently, it has been reported that agreement of $\alpha$-hemolytic streptococci identification by API 20 Strep and 16S rRNA gene sequencing was only $26 \%$ by species and $63 \%$ by streptococcal group [9].

The Rapid ID 32 Strep system is a more recent system, which consists of thirty two cupules and allows the identification of most streptococci and members of related genera encountered in medical and veterinary bacteriology in just 4 hours [10]. The aim of this study was to evaluate the reliability of Rapid ID 32 Strep in identifying isolates of $\alpha$-hemolytic streptococci from human dental plaque and to compare its identification capabilities at the species and

Received June 11, 2021; Revised July 20, 2021; Accepted July 22, 2021

*Corresponding author: Si Young Lee, Department of Microbiology and Immunology, College of Dentistry, Research Institute of Oral Science, Gangneung-Wonju National University, 7, Jukheon-gil, Gangneung 25457, Republic of Korea.

Tel: +82-33-640-2455, Fax: +82-33-642-6410, E-mail: siyoung@gwnu.ac.kr

Copyright ๑ 2021, Oral Biology Research Institute 
group levels.

\section{Materials and Methods}

\section{Bacterial isolates}

Eighty-five $\alpha$-hemolytic streptococci were isolated from the supragingival plaque of healthy persons. Supragingival plaque was transferred into a glass tube containing phosphate buffered saline (PBS) and glass beads (diameter $1 \mathrm{~mm}$ ). Dispersed plaque samples were diluted with PBS and plated on Mitis Salivarius agar plates (BD Bioscience, Sparks, MD, USA). After incubating at $37^{\circ} \mathrm{C}$ for 72 hours in aerobic conditions supplemented with $5 \% \mathrm{CO}_{2}$, one bacterial colony from each plaque sample was isolated randomly and grown in Brain Heart Infusion broth (Becton, Dickinson, and Company). Hemolysis of these isolates was examined on blood agar plates (KOMED, Seongnam, Korea). All volunteers who wanted to donate their plaques for this study were informed about the procedure in depth, and written consent from all was obtained for inclusion in the study. This study was approved by the Institutional Review Board of the Gangneung-Wonju National University Dental Hospital (IRB2011-2).

\section{Rapid ID 32 Strep identification}

Rapid ID 32 Strep (bioMérieux) testing was carried out according to the manufacturers' instructions, using the PCM-4862 BIOS software for API codes. After growth on sheep blood agar medium, a bacterial suspension was prepared in $2 \mathrm{~mL}$ of sterile water and adjusted to a 4 McFarland standard turbidity. Fifty-five microliters of the suspension were deposited into each well. After 4 hours of incubation at $37^{\circ} \mathrm{C}$, a reading was taken with a Mini API reader (bioMérieux). The Rapid ID 32 Strep database version used was V 2.30 .

\section{S rRNA gene amplification and sequencing}

The 16S rRNA gene was amplified using the bacteriumspecific universal primers 27F (5' -AGAGTTTGATCMTGGCTCAG-3') and 1492R (5'-TACGGYTACCTTGTTAC-
GACTT-3') to amplify a 1.5 -kb fragment $[11,12]$. PCR amplification was performed using a DNA thermal Cycler (GeneAMP PCR System 9700; Perkin Elmer, Waltham, MA, USA) under the following conditions: initial incubation at $95^{\circ} \mathrm{C}$ for 2 minutes, 34 cycles at $94^{\circ} \mathrm{C}$ for 1 minute, $55^{\circ} \mathrm{C}$ for 30 seconds, and $72^{\circ} \mathrm{C}$ for 1 minute, followed by final incubation at $72^{\circ} \mathrm{C}$ for 10 minute. Primers and excess nucleotides were removed using a PCR purification kit (Bioneer, Deajeon, Korea). DNA sequencing was performed by Macrogen (Seoul, Korea) using the PCR primers. The 16S rRNA gene sequences were subjected to BLAST analysis against the NCBI nucleotide database.

\section{Results}

The 16S rRNA gene sequencing results of eighty-five isolates showed $\geq 99 \%$ similarity to published species in NCBI BLAST data. The species identification of the eightyfive clinical isolates was accurately carried out by molecular methods, and the identification comparison results are shown in Table 1, along with the relative performance of

Table 1. Comparison of Rapid ID 32 Strep identification with $16 \mathrm{~S}$ rRNA gene sequencing identification of clinical $\alpha$-hemolytic streptococci at the group and species levels

\begin{tabular}{lcc}
\hline $\begin{array}{c}\text { Species by 16S rRNA } \\
\text { sequencing }\end{array}$ & $\begin{array}{c}\text { No. of } \\
\text { isolates }\end{array}$ & $\begin{array}{c}\text { Agreement by Rapid } \\
\text { ID32 Strep, n (\%) }\end{array}$ \\
\hline Mitis group & 10 & $7(70)^{\mathrm{a}}$ \\
S. mitis & 6 & $3(50)^{\mathrm{b}}$ \\
S. oralis & 2 & $2(100)$ \\
S. australis & 1 & $0(0)$ \\
Sanguinis group & 23 & $21(91)$ \\
S. sanguinis & 7 & $7(100)$ \\
S. gordonii & 13 & $13(100)$ \\
S. cristatus & 3 & $0(0)$ \\
Anginosus group & 28 & $23(82)$ \\
S. anginosus & 24 & $16(67)$ \\
S. constellatus & 4 & $4(100)$ \\
Salivarius group & 17 & $17(100)$ \\
S. salivarius & 17 & $17(100)$ \\
Mutans group & 7 & $6(86)$ \\
S. mutans & 7 & $6(86)$ \\
Total & 85 & $74(87)$ \\
Total agreement by group & & $68(80)$ \\
Total agreement by species & & \\
\hline
\end{tabular}

${ }^{a}$ Percentage of isolates assigned to correct group by a test. ${ }^{b}$ Percentage of isolates assigned to correct species by a test. 
the Rapid ID 32 Strep test method. Rapid ID 32 Strep correctly identified $80 \%$ of species and $87 \%$ of streptococcal groups. This signified higher identification success rates at the group level than at the species level. Rapid ID 32 Strep failed to correctly identify any of the three $S$. cristatus, one $S$. australis, and one $S$. tigurinus isolates.

\section{Discussion}

Gene sequencing analysis remains by far, the most reliable method for the laboratory identification of $\alpha$-hemolytic streptococci. Davies et al. [9] reported that fifty-six $\alpha$-hemolytic streptococcal isolates were identified using API 20 Strep (bioMérieux). When compared with the 16S rRNA gene sequencing identification, $26 \%$ of isolates were correctly identified by API 20 Strep at the species level. Davies et al. [9] used API 20 Strep instead of Rapid ID 32 Strep in their study for comparison of identification methods. In addition, blood was the main source of $\alpha$-hemolytic streptococci used in this study. Different streptococci isolation sources might also cause discrepancies in identification ability.

In 1984, API 20 Strep for species identification of streptococci associated with bovine mastitis was compared with conventional biochemical methods [13]. Using profile indexes and table data issued by the manufacturer, the API 20 Strep system identified $71.4 \%$ of strains. Hinnebusch et al. [14] previously reported the comparison between different bacterial identification methods for viridans group streptococci. Viridans group streptococci 36 stock strains and 167 single patient blood culture isolates) were assessed using API 20 Strep. API 20 Strep results corresponded with those of conventional biochemical identification in $74 \%$ of cases; using the recommended supplemental test, agreement was augmented in 9\% of the isolates. Disagreement with conventional biochemical methods occurred in 14\% of the commercial techniques.

The Rapid ID 32 Strep system is a suitable alternative for rapid identification of members of the Streptococcus genus and related genera. The Rapid ID 32 Strep system is easy to use in routine work and gives rapid results (within 4 hours). The main advantage of this system is its extensive database, which allows correct identification of most newly described species of medical or veterinary interest. Freney et al. [15] reported that the performance of the Rapid ID 32 Strep system in oral streptococci identification was good. However, additional tests were generally needed for complete identification of Streptococcus sanguis (7 of 8 strains tested), Streptococcus oralis (14 of 22), Streptococcus mitis (11 of 17), and Streptococcus pneumoniae (10 of 29). Most of the other streptococci (S. bovis, S. suis, and S. ubenis) were correctly identified without extra tests. For the other gram-positive species tested, results were in good agreement with the reference identification.

In our study, eighty-five $\alpha$-hemolytic streptococcal isolates were identified using 16S rRNA gene sequencing and Rapid ID 32 Strep. Rapid ID 32 Strep correctly identified $80 \%$ of isolates at the species level. This system generally displayed excellent identification ability in our study. Rapid ID 32 Strep failed to correctly identify $S$. cristatus, $S$. australis, and $S$. tigurinus isolates, because the database used in our study did not contain the identification data for these species. $S$. australis and $S$. tigurinus are novel, recently identified oral streptococci [16-18]. Further database development may help improve its performance; in particular, an improvement in its ability to identify $S$. anginosus, $S$. cristatus, $S$. australis, and $S$. tigurinus would greatly enhance its reliability.

In our study, we showed that the Rapid ID 32 Strep correctly identified $80 \%$ of species and $87 \%$ of streptococcal groups.

\section{Acknowledgements}

The author appreciates the helpful assistance of YH Kim for sample collection.

\section{Conflicts of Interest}

The author declares no competing interests.

\section{ORCID}

\author{
Si Young Lee \\ https://orcid.org/0000-0001-8826-1413
}




\section{References}

1. Facklam R. What happened to the streptococci: overview of taxonomic and nomenclature changes. Clin Microbiol Rev 2002;15:613-630. doi: 10.1128/CMR.15.4.613630.2002.

2. Coykendall AL. Classification and identification of the viridans streptococci. Clin Microbiol Rev 1989;2:315-328. doi: 10.1128/CMR.2.3.315.

3. Bizzini A, Greub G. Matrix-assisted laser desorption ionization time-of-flight mass spectrometry, a revolution in clinical microbial identification. Clin Microbiol Infect 2010;16:1614-1619. doi: 10.1111/j.1469-0691.2010.03311. $\mathrm{x}$.

4. Bosshard PP, Abels S, Altwegg M, Böttger EC, Zbinden R. Comparison of conventional and molecular methods for identification of aerobic catalase-negative grampositive cocci in the clinical laboratory. J Clin Microbiol 2004;42:2065-2073. doi: 10.1128/JCM.42.5.20652073.2004.

5. Chen CC, Teng LJ, Chang TC. Identification of clinically relevant viridans group streptococci by sequence analysis of the $16 \mathrm{~S}-23 \mathrm{~S}$ ribosomal DNA spacer region. J Clin Microbiol 2004;42:2651-2657. doi: 10.1128/JCM.42.6.26512657.2004 .

6. Kawamura Y, Hou XG, Sultana F, Miura H, Ezaki T. Determination of $16 \mathrm{~S}$ rRNA sequences of Streptococcus mitis and Streptococcus gordonii and phylogenetic relationships among members of the genus Streptococcus. Int J Syst Bacteriol 1995;45:406-408. doi: 10.1099/00207713-45-2406. Erratum in: Int J Syst Bacteriol 1995;45:882.

7. Clinical and Laboratory Standards Institute. Interpretive criteria for identification of bacteria and fungi by DNA target sequencing: approved guideline. Wayne: Clinical and Laboratory Standards Institute; 2008.

8. Biomerieux. API 20 Strep 008041-3. Marcy-1'Etoile: Biomerieux; 1984.

9. Davies AP, Reid M, Hadfield SJ, Johnston S, Mikhail J, Harris LG, Jenkinson HF, Berry N, Lewis AM, El-Bouri K, Mack D. Identification of clinical isolates of $\alpha$-hemolytic streptococci by $16 \mathrm{~S}$ rRNA gene sequencing, matrix-assisted laser desorption ionization-time of flight mass spectrometry using MALDI Biotyper, and conventional phenotypic methods: a comparison. J Clin Microbiol 2012;50:4087-4090. doi: 10.1128/JCM.02387-12.

10. Biomerieux. [Rapid ID 32 Strep REF 32 600]. Marcyl'Etoile: Biomerieux; 2009. French.

11. Sagar K, Singh SP, Goutam KK, Konwar BK. Assessment of five soil DNA extraction methods and a rapid laboratory-developed method for quality soil DNA extraction for $16 \mathrm{~S}$ rDNA-based amplification and library construction. J Microbiol Methods 2014;97:68-73. doi: 10.1016/ j.mimet.2013.11.008.

12. de Lillo A, Ashley FP, Palmer RM, Munson MA, Kyriacou L, Weightman AJ, Wade WG. Novel subgingival bacterial phylotypes detected using multiple universal polymerase chain reaction primer sets. Oral Microbiol Immunol 2006;21:6168. doi: 10.1111/j.1399-302X.2005.00255.x.

13. Poutrel B, Ryniewicz HZ. Evaluation of the API 20 Strep system for species identification of streptococci isolated from bovine mastitis. J Clin Microbiol 1984;19:213-214. doi: 10.1128/jcm.19.2.213-214.1984.

14. Hinnebusch CJ, Nikolai DM, Bruckner DA. Comparison of API Rapid Strep, Baxter MicroScan Rapid Pos ID Panel, BBL Minitek Differential Identification System, IDS RapID STR System, and Vitek GPI to conventional biochemical tests for identification of viridans streptococci. Am J Clin Pathol 1991;96:459-463. doi: 10.1093/ajcp/96.4.459.

15. Freney J, Bland S, Etienne J, Desmonceaux M, Boeufgras JM, Fleurette J. Description and evaluation of the semiautomated 4-hour rapid ID 32 Strep method for identification of streptococci and members of related genera. J Clin Microbiol 1992;30:2657-2661. doi: 10.1128/jcm.30.10.26572661.1992.

16. Willcox MD, Zhu H, Knox KW. Streptococcus australis sp. nov., a novel oral streptococcus. Int J Syst Evol Microbiol 2001;51(Pt 4):1277-1281. doi: 10.1099/00207713-51-41277.

17. Zbinden A, Mueller NJ, Tarr PE, Eich G, Schulthess B, Bahlmann AS, Keller PM, Bloemberg GV. Streptococcus tigurinus, a novel member of the Streptococcus mitis group, causes invasive infections. J Clin Microbiol 2012;50:29692973. doi: 10.1128/JCM.00849-12.

18. Zbinden A, Mueller NJ, Tarr PE, Spröer C, Keller PM, Bloemberg GV. Streptococcus tigurinus sp. nov., isolated from blood of patients with endocarditis, meningitis and spondylodiscitis. Int J Syst Evol Microbiol 2012;62(Pt 12):2941-2945. doi: 10.1099/ijs.0.038299-0. 